\author{
Jan A. Choroszy (iD https://orcid.org/0000-0003-0447-9277 \\ Uniwersytet Wrocławski \\ jan.choroszy@uwr.edu.pl
}

\title{
Kresowość Stanisława Vincenza
}

\section{Stanisław Vincenz’s Borderlands}

Abstract: Stanisław Vincenz oeuvre, the cycle entitled On the High Uplands, in particular, enriched the borderlands' tradition with original and separate elements. What is most important for the writer in the history of the borderlands is the multiethnic and multilinguistic social tissue. What emerges to the foreground in his cycle of essays, Dialogi lwowskie [Lviv Dialogues], is the memory of people who considered this city as the top intellectual metropolis of the multinational Polish Republic. The provincial borderland character of Kolomyia and Krivorivnia in Vincenz's works was subject to the polyphony of cultures within local communities. His hometown, Sloboda Rungurska, became a space of artistic freedom and activity. Borderlands understood in cultural terms were an axiological category, which combined myths and phantasms of Christianity, Polishness in its most noble form and heroic life lived by the ethos of gentry and knighthood. Vincenz's understanding of the Borderlands touches on axiology, with reference to the Jagiellonian tradition, however, it also transgresses it on the ontological and ethical planes.

Keywords: Stanisław Vincenz, Borderlands, On the High Uplands, Dialogi lwowskie [Lviv Dialogues], Hutsul Region, Galicia, Lviv, Kolomyia, Krivorivnia, Sloboda Rungurska

Streszczenie: Twórczość Stanisława Vincenza, a zwłaszcza cykl Na wysokiej potoninie, wnosi do tradycji kresowej pierwiastki oryginalne i osobne. W dziejach Kresów najważniejsza dla pisarza była wieloetniczna i wielojęzyczna tkanka społeczna. W eseistycznym cyklu Dialogi lwowskie na plan pierwszy wysunęła się pamięć o ludziach, którzy nadawali miastu rangę intelektualnej metropolii wielonarodowej Rzeczypospolitej. Prowincjonalna kresowość Kołomyi i Krzyworówni podlegała u Vincenza zasadzie polifonii kultur w obrębie wspólnot lokalnych. Rodzinna Słoboda Rungurska stała się przestrzenią twórczej swobody i działania. Kulturowo pojmowana kresowość była kategorią aksjologiczną - łączyła mity i fantazmaty przedmurza chrześcijaństwa, najszlachetniejszej polskości oraz heroiczności szlechecko-rycerskiego życia. Vincenzowskie pojmowanie Kresów styka się z tą aksjologią w przywołaniu tradycji jagiellońskiej - lecz przekracza ją w płaszczyźnie ontologicznej i etycznej.

Słowa kluczowe: Stanisław Vincenz, Kresy, Na wysokiej potoninie, Dialogi lwowskie, Huculszczyzna, Galicja, Lwów, Kołomyja, Krzyworównia, Słoboda Rungurska 
Kresowość Stanisława Vincenza wydaje się i oczywista, i dość skomplikowana ${ }^{1}$. Została rozpoznana natychmiast po wydaniu pierwszego tomu cyklu huculskiego w 1936 roku, po drugiej wojnie światowej uznano ją za fundamentalny składnik osobowości twórczej osiadłego w Grenoble pisarza ${ }^{2}$. Stwierdzenie, że wielowarstwowe i złożone dzieło Homera Huculszczyzny należy do bogatego zbioru najróżniejszych tekstów literackich, w których obszary pograniczne dawnej Rzeczypospolitej są substancją świata przedstawionego, trzeba jednak uzupełnić zdaniem, iż wnosi zarówno do tej kolekcji, jak i utrwalonego w niej obrazu Kresów liczne pierwiastki oryginalne i - w dużym stopniu - osobne. Napisała o tym Nina Taylor-Terlecki w znakomitym eseju, opublikowanym w 1992 roku $^{3}$. Zasygnalizował to Stanisław Nicieja, przywołując w Kresowej Atlantydzie pogłębioną i trafną opinię Joanny Tokarskiej-Bakir, a jednocześnie wyostrzył (chyba mimowolnie) - lokując w sąsiedztwie podrozdział poświęcony Huculszczyźnie Ferdynanda Antoniego Ossendowskiego (tak oto do największej roli urósł najmniejszy wspólny mianownik)4. Wydaje się, że warto podjąć jeszcze jedną próbę refleksji nad niektórymi aspektami kresowości Vincenza, aby jej najważniejsze składniki nie dostały się łatwo we władanie stereotypus 5 .

Nina Taylor-Terlecki opisała dzieło Stanisława Vincenza na tle tradycji kresowej ufundowanej przez Adama Mickiewicza i kultywowanej przez autorów, których zwyczajowo ciagle nazywamy współczesnymi, rówieśnych lub młodszych od twórcy Potoniny, publikujących po 1939 roku. Ramy historyczne świata przedstawionego tetralogii huculskiej nie przystają jednak do czasu zatrzymanego w tych tekstach, przez co najważniejsze dzieło Vincenza tylko

1 O kwestiach oczywistych i nieoczywistych w postrzeganiu kresów/Kresów zob. Kresy pojęcie i rzeczywistość, red. K. Handke, Warszawa 1997; S. Uliasz, Literatura Kresów - kresy literatury. Fenomen Kresów Wschodnich w literaturze polskiej dwudziestolecia międzywojennego, Rzeszów 1994.

2 J.A. Choroszy, Huculszczyzna w literaturze polskiej, Wrocław 1991, s. 293-311; B. Hadaczek, Huculski świat Stanistawa Vincenza [w:] tegoż, Kresy w literaturze polskiej XX wieku. Szkice, Szczecin 1993.

3 N. Taylor-Terlecki, Stanistaw Vincenz i tradycja kresowa [w:] Świat Vincenza. Studia o życiu i twórczości Stanistawa Vincenza (1888-1971), red. J.A. Choroszy, J. Kolbuszewski, Wroclaw 1992.

4 S.S. Nicieja, Kresowa Atlantyda. Historia i mitologia miast kresowych, t. 4: Kotomyja, Żabie, Dobromil, Opole 2014, s. 141-144. Oto przywołane zdania badaczki i eseistki: „Dzięki Vincenzowi wierchowiński zakątek Karpat Wschodnich stał się (...) kolejnym w naszej literaturze mitycznym zagłębiem i matecznikiem. Silniejsza od nacjonalizmu idea jagiellońska sprzyjała współżyjącym tam nacjom, religiom i stanom. Huculszczyzna, pogranicze narodów i kultur, pojawia się w eposie Vincenza jako idealizacja »ściślejszej ojczyzny«, które to pojęcie na wiele lat przed epoką europejskich regionów autor sagi huculskiej wprowadził do języka polskiego".

O różnych rejestrach mitologizacji pisał w ujęciu diachronicznym Jacek Kolbuszewski (tenże, Kresy, Wrocław 1995). Sedno problemu ujął w 1946 roku Józef Wittlin: „Nostalgia lubi fałszować także i smak, każąc nam dziś odczuwać samą tylko słodycz Lwowa. Znam jednak ludzi, którym Lwów był czarą goryczy" (tenże, Mój Lwów, Wrocław 2017, s. 19). Zob. G. Gauden, Lwów - kres iluzji. Opowieść o pogromie listopadowym 1918, Kraków 2019. 
pośrednio komunikuje się z nimi, a z powodu znanych perypetii wydawniczych nie mogło w zauważalnym stopniu wpływać na ich autorów (wyjątkiem jest Dolina Issy Czesława Miłosza ${ }^{6}$ ). Jako stały czytelnik „Kultury”, „Wiadomości Literackich" i pomniejszych czasopism emigracyjnych Vincenz miał dobrą orientację w nurtach pisarstwa kresowego, lecz zachował do niego spory dystans, o czym świadczy sposób skomponowania i sens wspomnień zawartych w Dialogach lwowskich.

W tym eseistycznym cyklu, pisanym na fantastyczne (nierealne), jak się okazało, zamówienie Karola Kuryluka i dla odbiorcy krajowego, na plan pierwszy wysunęła się pamięć o ludziach, którzy wypełniali przestrzeń miasta-legendy i nadawali jej rangę intelektualnej metropolii wielonarodowej Rzeczypospolitej ${ }^{\top}$. Z perspektywy czasu, w oddaleniu, po doświadczeniu Zagłady, w obliczu nagich faktów wojennej śmierci przyjaciół i krewnych, wobec przesiedlenia ocalałych - Vincenz utwierdzał się w przekonaniu, że w zaistnieniu i historycznym trwaniu Kresów najważniejsza była wieloetniczna i wielojęzyczna społeczna tkanka, że kresowe wspólnoty lokalne, zarówno we Lwowie, jak i w Kołomyi, konstytuowały się na płaszczyźnie spotkania i dialogu, polifonii kultur. O stolicy Galicji jako tyglu, w którym stapiały się materialne i duchowe składniki należące do tradycji Wschodu i Zachodu, pisał pod koniec XIX wieku Władysław Łoziński ${ }^{8}$, lecz autor Dialogów lwowskich koncentrował się w retrospekcji przede wszystkim na fenomenie miasta czerpiącego intelektualną energię z otwartości elit (utrzymywanie mocnych więzi z twórcami kultury europejskiej było dodatkową wartością „kosmopolitów”). Doceniając Lwów jako filar polskiej tradycji kresowej, rozumiejąc wszystkie aspekty polsko-ukraińskiego sporu o miasto, kulminującego podczas wojny polsko-ukraińskiej i toczonego po 1945 roku na różnych forach, dystansując się od każdego nacjonalizmu, Vincenz opisywał to, co było jego najważniejszym lwowskim doświadczeniem, i przesuwał punkt ciężkości w pojęciu Kresów na splot wielu tradycji duchowych i nurtów intelektualnych.

W ławkach kołomyjskiego gimnazjum, dzielącego budynek z gimnazjum ukraińskim ${ }^{9}$ zasiadali obok siebie uczniowie należący do różnych kultur, potomkowie bardziej lub mniej spolonizowanych pokuckich rodów, dzieci przemysłowców, urzędników, lekarzy i prawników, należące do sfer ziemiańskiej i mieszczańskiej. Szkolne przyjaźnie rozwijały się ponad stanowymi barierami, znosiły nieufność i obcość, otwierały drzwi domów, w których unosiły się

6 M. Ołdakowska-Kuflowa, Stanistaw Vincenz - pisarz, humanista, orędownik zbliżenia narodów. Biografia, Lublin 2006, s. 344; C. Miłosz, R. Gorczyńska (E. Czarnecka), „Podróżny świata". Rozmowy, Kraków 2002, s. 125-126.

7 S. Vincenz, Dialogi lwowskie [w:] tegoż, Po stronie dialogu, t. 2, Warszawa 1983.

8 W. Łoziński, Ztotnictwo lwowskie w dawnych wiekach 1384-1640. Lwów starożytny. Kartki z historii sztuki i obyczajów, cz. 1, Lwów 1889, s. 5-6.

9 M. Ołdakowska-Kuflowa, dz. cyt., s. 52. 
aury zróżnicowanych tożsamości ${ }^{10}$. Ludzka wielość nie szukała usprawiedliwienia czy ideowego uzasadnienia - była naturalnym stanem pogranicza, zarówno rezultatem dziejów rozgrywających się na tle przestrzeni, jak i przede wszystkim poddaną młodości sferą codziennego rówieśniczego życia. Na marginesie uwagi lokowały się dziesiątki obrazów składających się na kołomyjską wieloetniczną codzienność, sylwetki osób, których istnienie nie domagało się stałego potwierdzenia, czy melodie zdań ledwo dosłyszalnie krzyżujących się w targowym gwarze. Wszystkie one były zestrojone w kresowym universum, wtapiały się w miejską tkankę społeczną i lokalną wspólnotę. Po Zagładzie, a jeszcze wcześniej po uwolnieniu upiorów nacjonalizmu okazało się, jak komplementarny był ten pograniczny świat i jak kruchy ${ }^{11}$.

Kresowość prowincjonalna, wiejsko-dworska, przedstawiona w dziele Vincenza, komponowała się z innych składników i w innych proporcjach, a także podlegała zasadzie polifonii kultur w obrębie wspólnot lokalnych - bodaj najwyraźniej zostało to wypowiedziane we wstępie do budapeszteńskiej edycji Madonny Busowiskiej Władysława Łozińskiego ${ }^{12}$, przewinęło się w kilku esejach o kulturze ludowej, a najpełniej wyraziło się w Potoninie. Ponieważ każda społeczność może być rozmaicie identyfikowana, a jej miękkie granice wtapiają się zawsze w szersze wspólnoty, to kluczowe znaczenie ma kwestia tożsamości zespolona z poczuciem zakorzenienia. Właśnie dlatego w prozie Vincenza wszyscy są skądś, określani na różne sposoby, lecz zawsze konkretnie i możliwie najdokładniej, w myśl zasady, że ludzi żabiowskich absolutnie nie można pomylić z bystreckimi. Przysiółek, wioska, dolina górskiego potoku albo pasmo górskie są czymś więcej niż miejscem urodzenia lub życia, albowiem - ukształtowane jako wypadkowa natury i przetwórczości ludzkiej - naznaczają człowieka w każdym wymiarze jego istnienia: w fizjologii, języku, pracy, myśleniu i wyobraźni, religijności, odziedziczonym doświadczeniu etc.

Wieloetniczna mała wspólnota lokalna z reguły wymusza respekt dla różnorodnych składników kultury, lecz jednocześnie tworzy płaszczyznę współuczestnictwa i dzielenia losu w dobrym i złym. Etniczna obcość ustępuje przed swojskością sąsiedztwa, inny język powoli staje się zrozumiały i nie udaremnia porozumienia, odmienne tradycje i obrzędy są zaproszeniem do wspólnego świętowania, a pożytek ze współpracy staje się korzyścią docenianą przez wszystkich. Urodzaj i klęska są przeżywane wspólnotowo. Inność przestaje być wrogą obcością, a inny nie wywołuje lęku czy agresji. W takim modelu wspólnoty lokalnej nieuniknione są kryzysy, lecz ich przezwyciężanie nie powoduje

10 S.S. Nicieja, dz. cyt., s. 18 i n.

11 S. Vincenz, Ofiary w Kotomyi. Wspomnienie o Żydach kotomyjskich [w:] tegoż, $Z$ perspektywy podróży, Kraków 1979. Zob. M. Czarnik, Stanistawa Vincenza filozofia wspótistnienia w perspektywie powojennych stosunków polsko-żydowskich, „Tematy i Konteksty” 2017, nr 7.

12 S. Vincenz, „Madonna Busowiska”. Stowo wstępne [w:] tegoż, Po stronie dialogu, dz. cyt., t. 2. 
destrukcji społecznej tkanki - aż do momentu, kiedy pojawia się nacjonalizm w wersji agresywnej i wykluczającej albo brutalny antysemityzm (w końcu podbudowany faszyzmem).

Główny projekt pisarski Vincenza, ewoluująca i poszerzająca horyzont ideowy Potonina, odwołuje się do świata posadowionego na fundamentach ustroju Galicji z drugiej połowy XIX wieku: wolnego od pańszczyzny, oddalonego od wojen, wychodzącego dopiero na spotkanie rewolucji przemysłowej, akceptującego różnorodność językową i religijną. W peryferyjnej rzeczywistości władza pozostawia ludziom rozległą przestrzeń wolności, a ona rozciąga się też na sferę religijności, która bliższa jest zaspokajaniu autentycznych potrzeb duchowych niż wypełnianiu kościelnych przepisów i nakazów. W „ojczyźnie człowieczej” świat, choć nigdy nie jest bezbłędnie urządzony, pozwala na trwanie pokoleń, polegające nie tylko - a właściwie najmniej - na przekazywaniu życia i dobytku, lecz przede wszystkim na kultywowaniu tradycji i mitów, w nich bowiem zapisują się zarówno archaiczna, wręcz założycielska, prawda starowieku, jak i wzór postępowania w każdych okolicznościach, a więc także w nowych czasach. Na miejscowe pismo światowe (a więc księgę natury) nakładają się kroniki góralskich rodów i rodzin przybyłych z własnych historii i z osobnymi dziejami - wszystkie te utekstowione składniki stały się tworzywem epickiego dzieła, splotły się w narracji intencjonalnie uwzględniającej każdy wątek, ponieważ dopiero ich suma składa się na wiarogodny i prawdopodobny (choć, jak twierdzą krytyczni, nieprawdziwy ${ }^{13}$ ) obraz rzeczywistości ${ }^{14}$.

Wielokrotnie pisano o zaludniających dzieło Vincenza Hucułach, Żydach, Ormianach, Polakach, Romach, Węgrach czy Niemcach, żyjących w społecznej symbiozie, lecz właściwie dopiero pojęcie wspólnoty lokalnej odkrywa zasadę współistnienia: świat przedstawiony Potoniny jest uporządkowaną, a przy tym permanentnie otwartą, kompozycją zdialogizowanych opowieści o mieszkańcach kilku okolic (Krzyworównia, Żabie, Jasienów, Jaworów, Bystrec, Słoboda Rungurska) i rozleglejszych krain (Wierchowina, czyli Czarnohora, Pokucie, Bukowina) - identyfikujących się z miejscem i krajobrazem, obdarzonych pamięcią o przeszłości, utrzymujących relacje z innymi, poczuwających się do odpowiedzialności za los zbiorowości. Rozmaitość i intensywność strumieni mowy ${ }^{15}$ objętych narracją Potoniny nie wyczerpuje istoty dialogu toczonego w dziele, ponieważ głębię buduje w nim przede wszystkim kulturowe (stanowe, etniczne i religijne) zróżnicowanie precyzyjnie wykreowanych i wyposażonych w bogatą osobowość interlokutorów. Bez dysput religijnych uwzględniających punkty widzenia chasydów i wschodniokarpackich pasterzy, debat

13 A. Madyda, Stanistawa Vincenza antropologia kultury huculskiej [w:] tegoż, Od filologii do antropologii. Szkice, Toruń 2015, s. 60.

14 M. Kaczmarek, Proza pamięci. Stanistawa Vincenza pamięć i narracja, Toruń 2009, s. $230-272$.

15 J. Ługowska, Vincenz-mistrz stowa mówionego, Wrocław 2015, s. 77-90. 
o oświacie odwołujących się do góralskiej nieufności, dyskursu o wolności uwzględniającego huculską mitologię, a wreszcie bez sporu o nowoczesność angażującego bywałych w świecie dziedzica i Ormianina, bez konsekwentnego konfrontowania ze sobą, na sposób sokratejski, rzeczników wielu światopoglądów i reprezentantów licznych tradycji duchowych dzieło Vincenza, może $\mathrm{z}$ wyjątkiem Zwady, powieści o pracy, straciłoby konstrukcję nośną, osunęłoby się w bezkształtny stos epizodów powiązanych motywem regionalistycznym.

Kreacja postaci, sytuacji i zdarzeń ma silne podłoże biograficzne: w strukturze fabularnej cyklu huculskiego legenda rodzinna jest mocno wyeksponowana, a Vincenz wielokrotnie podkreślał nakładanie tożsamości fikcyjnych osób na własne doświadczenia i przekonania, co skrupulatnie zanotowała jego żona. Odsuwając na bok dociekanie, kto w Potoninie i kiedy staje się porte-parole autora, można postawić tezę, że ekstrapolowany w przeszłość, skondensowany i uporządkowany zapis toczącego się dialogu kultur opiera się na realnym, autopsyjnym doświadczeniu pisarza, odnosi się do rozpoznanych przezeń reguł życia społecznego, uwarstwienia i relacji łączących grupy ludzkie, instytucji i kanałów komunikacji, słowem - tych wszystkich czynników, które stanowią wewnętrzny mechanizm wielokulturowej wspólnoty. Polifoniczność świata nie tylko jest pochodną rezygnacji z zastosowania narracji auktorialnej, skrajnie zobiektywizowanej i nadrzędnej, a więc z odmowy zajęcia stanowiska hegemona ujawnionych w dziele świadomości, lecz także wynika - w wielkim stopniu z zakresu i skali zgromadzonych doświadczeń (spotkanych ludzi, odbytych rozmów, poznanych opinii, zaobserwowanych postaw itd.) oraz umiejętności ich literackiej transpozycji. Jednym z najważniejszych faktów w tym zakresie, analogicznym do czyjegoś urodzenia się w rodzinie mieszanej, był wczesny kontakt z dialektem huculskiej niańki, najpierw czyniący z dwu- i wielojęzyczności naturalny atrybut życia codziennego, a następnie otwierający Vincenza na kulturę sąsiedzkiej grupy etnicznej: folklor huculski i literaturę ukraińską. Empiria mierzyła się jednocześnie z rozmaitością obiegowych poglądów i ludzkich postaw, pozwalała weryfikować ich pewniki, a w konsekwencji obalać stereotypy, kiedy indziej odkrywała istnienie innych sposobów percepcji świata, rzutowała na sposób myślenia nie tylko dziecka, ale i dojrzałego mężczyzny. Wielość przekroczeń, jakie stawały się udziałem Vincenza od wczesnego dzieciństwa, ich zakres i skala intensywności, wynikające z mobilności rodziny i osobistej aktywności, z życia fizycznie i mentalnie rozciągniętego najpierw między Słobodą Rungurską a Krzyworównią, później między Słobodą a Bystrecem, z dwóch związków małżeńskich oraz sporej liczby tak zwanych familiantów rodu Przybyłowskich (z Baziem Przybyłowskim na czele) - wszystko to składało się na doświadczenie unikalne, a zarazem (tylko w pewnym stopniu) typowe w rzeczywistości kresowej, o czym trafnie pisał Aleksander Hertz ${ }^{16}$.

16 A. Hertz, Wyznania starego cztowieka, Londyn 1979, s. 285-286: „Był zaiste postacią renesansową. Nie bardzo pod tym względem - jak i pod wieloma innymi - pasował do Polski 
Widzenie wspólnot lokalnych, odpowiadających kryteriom geograficznym kresowości, nie pozostawało niezmienne i statyczne, było wzbogacane w efekcie nawarstwiania się odległych - „światowych” - przygód duchowych, do których zaliczyć można tak oczywiste fakty, jak studia w międzynarodowym środowisku Uniwersytetu Wiedeńskiego, służba wojskowa w kosmopolitycznej cesarsko-królewskiej armii, znajomość oraz myślowa zależność od Rudolfa Marii Holzapfla, i mniej wyeksponowane zdarzenia, takie jak przyjaźń z obywatelami sfederowanej Szwajcarii czy udział w ceremoniach religijnych warszawskich chasydów. W każdym zetknięciu z innością, wielością i różnorodnością ugruntowywało się przekonanie, że to w bliższych ojczyznach rodzą się pokolenia, że w dialektach tkwi część tożsamości i że dusza nie ma narodowości. Europejski humanizm Vincenza spotykał się ze światem partykularnym, czyniąc go małą Itaką - nie tylko osadzając w ramach i kontekście kulturowym kontynentu poskładanego z regionów, ale wręcz identyfikując z ojczyzną człowieczą w podwójnym sensie: z archaiczną formą kultury pasterskiej oraz homerycką wspólnotą bogów i ludzi, ziemi i zwierząt.

Równie istotna, zwłaszcza w kształcie literackiego obrazu Kresów w Potoninie, była zmiana perspektywy w 1940 roku. Emigracja, co Mickiewicz wypowiedział najgłośniej w apostrofie do Litwy na początku Pana Tadeusza, nadała inny, głębszy sens utrwalonym w pamięci obrazom okolic domowych - tego dotyczyła notatka z września 1941 roku zapisana w brulionie Outopos ${ }^{17}$. Inaczej niż u romantycznego poety tęsknota do porzuconych krajobrazów i ludzi splatała się u Vincenza ze świadomością końca życia w tradycyjnych, a przynajmniej dotychczasowych ramach: najpierw inwazja Sowietów syrojidów, później antypolskie akcje ukraińskich nacjonalistów, a wreszcie Zagłada zmieniały oswojony świat nie do poznania, rujnowały jego fundamenty i na zawsze pochłaniaty jak fale oceanu. Do Budapesztu docierali naoczni świadkowie i listowne relacje. Katastrofa stała się udziałem zarówno emigrantów, jak i pozostałych na miejscu - wszyscy byli ofiarami ${ }^{18}$. To właśnie wtedy pod piórem piewcy Huculszczyzny zaczęła się kształtować wizja słowiańskiej Atlantydy, obraz zaprzepaszczonego świata, który był „dobry, mądry i szczęśliwy”.

ówczesnej i do okolic Kołomyi. Jego talenty gospodarcze były w rzeczywistości jedną ze stron jego zamiłowania do przygody, jego bujnej natury, tego élan vital, jaki w nim stale dominował. To też był Polak kresowy, pełen temperamentu, pełen wigoru, zawsze szukający czegoś nowego. Nic mu nie było bardziej obce niż rutyna i małostkowość. I był człowiekiem wielkiej fantazji”.

17 S. Vincenz, Outopos. Zapiski z lat 1938-1944, autograf odczytał A. Vincenz, oprac. J.A. Choroszy, Wrocław 1992, s. 138-139.

18 Ołdakowska-Kuflowa przywołuje list Vincenza do Gustawa Goldberga z 1948 roku: „Właściwie nie miałbym gustu pokazać się, a raczej stąpić nogą na ziemi Słobody, Kołomyi, Stanisławowa czy Lwowa. Wszędzie śmierć, to mniejsza, ale wszędzie podeptanie człowieczeństwa i bezsens tych niezliczonych śmierci, a przez to i życia”; M. Ołdakowska-Kuflowa, dz. cyt., s. 239. 
Intelektualnym podłożem postawy Vincenza była, o czym wiadomo, tradycja jagiellońska ${ }^{19}$. Pisarz widział w niej zarówno historyczny już projekt geopolityczny, zamysł tworzenia i poszerzania rozległej wspólnoty kultury europejskiej - łączenia Wschodu z Zachodem, jak i - a może przede wszystkim otwarcie się na innych. Zetknął się z koncepcjami federalistycznymi Józefa Piłsudskiego, uczestniczył w ich uskutecznianiu, a wkrótce z bliska, jako urzędnik państwowy, publicysta i działacz społeczny, obserwował fatalny obrót, jaki przybrały sprawy mniejszości narodowych w Polsce. Jedyną płaszczyzną realnego, choć poddanego licznym ograniczeniom nawiązywania do idei jagiellońskiej były wspólnoty lokalne i ich sublimacja, czyli sfera prywatności, a po 1930 roku - projekt pisarski pod nazwą Potonina. Aktywność Vincenza w Towarzystwie Przyjaciół Huculszczyzny, wybór „ochrony swojszczyzny” jako dziedziny, za którą odpowiadał w stowarzyszeniu, powołanie czasopisma „Na Szlaku” poświęconego Karpatom Wschodnim, wspieranie huculskich twórców (najbardziej znany z nich to Petro Szekeryk-Donykiw ${ }^{20}$ ), inicjowanie rozległej akcji promocji regionu jako fenomenu kultury ludowej - motywem podjętych działań było bezinteresowne oddanie środowisku pojmowanemu jako wspólnota. Każdy nacjonalizm, zarówno polski, jak i ukraiński, pisarz odrzucał. Na wielu fotografiach z Bystreca i Żabiego, a więc rejestrujących zdarzenia zaistniałe po wybudowaniu (w 1927 roku) domu pod Czarnohorą, Vincenz jest blisko huculskich znajomych i swojaków (dla dzieci - „wujków”), a kiedy w 1935 roku gościł włoskiego etnologa Lidia Ciprianiego, to pokazywał mu najpiękniejsze widoki na góry, przed obiektywem stawiał zaś charakterystycznych przedstawicieli kilku góralskich rodów i własnych sąsiadów. Najbardziej jagiellońską scenę utrwalił Cipriani na tle ganku przed domem w Bystrecu: rodzina Vincenzów, Hucułki, Rozalia Eisenmann z Warszawy, Marian Haleniak z Kołomyi, Zbindenowie z Berna i Włoszka z Florencji, dzieci i dorośli, domownicy i goście, wszyscy zajmują miejsce w przestrzeni uwolnionej przez gospodarza z etnicznych i stanowych barier ${ }^{21}$. Krzyworówniańska dworskosś i patriarchalność (nie wolna od niejednoznacznych zjawisk obyczajowych) znalazła w Bystrecu formę wysublimowaną: uczciwe i oddane wspólnocie sąsiedztwo, jak najdalsze od inteligenckiej ludomanii, a - wręcz przeciwnie - oparte na rzetelnym rozpoznaniu autonomii archaicznej kultury pasterskiej Hucułów, odseparowane jednocześnie od środowiskowej presji na zachowywanie dystansu i manifestowanie kulturalnej wyższości Polaków. W bystreckiej „ojczyźnie człowieczej” każdy miał prawo być sobą, a obowiązkiem „pracownika duchowego” było dostrzeżenie w innym osoby - jednostki należącej do wspólnoty związanej z krajobrazem.

19 A. Madyda, Vincenz czytany dzisiaj [w:] tegoż, Od filologii do antropologii..., dz. cyt., s. 36-37.

20 A. Wielocha, Petro Szekeryk-Donykiw. Biografia nie catkiem kompletna, „Płaj” 2007, t. 35.

21 „Dialog o losie i duszy. Stanistaw Vincenz (1888-1971)”. Katalog wystawy, oprac. J.A. Choroszy, Wrocław 2016, s. 15. 
Wydaje się bardzo prawdopodobne, że właśnie w Bystrecu kształtowała się fenomenalna zdolność pisarza do kreowania pełnowymiarowych, plastycznych i zindywidualizowanych postaci licznych huculskich bohaterów Potoniny.

Bystrec został przez Vincenza wybrany, natomiast Słoboda Rungurska była zastana i w doświadczeniu kresowości odegrała inną rolę. W atmosferze naftowej gorączki z ostatnich lat XIX wieku nie spełniała warunków przestrzeni szczęśliwego dzieciństwa (tą była Krzyworównia z dworem Przybyłowskich, opisywana jako świat „dobry, mądry i szczęśliwy”), niemniej jednak - zwłaszcza z perspektywy czasu i po odgadnięciu kluczowej zasady organizującej Potoni$n \ell-$ w osobistej refleksji i literackiej kreacji przybierała formę miejsca twórczej swobody i działania. To, co dawniej nazywano duchem kupieckiej zarobkowości, a dzisiaj - przedsiębiorczością, Vincenz widział jako dokonanie zaledwie dwóch pokoleń własnej rodziny i jako przedmiot pionierskiej dumy z realizacji wielkiego projektu przemysłowego. Każdą przetwórczość ludzką, odciskającą piętno na pejzażu i czyniącą z dziewiczego krajobrazu tło dziejów, pisarz - trochę za Jerzym Stempowskim ${ }^{22}$ - potrafil dostrzec i odczytać, istotą kultury była przecież jej wielowarstwowość i wieloznakowość, w Słobodzie miał jednak do czynienia z epokowym osiągnięciem własnego ojca. To, co wcześniej stworzyli na Pokuciu antenaci Przybyłowscy i Torosiewicze, zostało dopełnione (a może i zrównoważone) przez Vincenzów, a w rodzinie, w której dziedziczyło się nie tylko nazwiska, ale i imiona, miało to pewną wagę. Założyciele i budowniczowie nafciarskiej osady (przystanek kolejki wąskotorowej nazywał się Słoboda Rungurska Kopalnia), a także ich potomkowie tworzyli niemal z niczego nowy świat poddany nieskrępowanej woli wizjonerów, własne losy na zawsze, jak się zdawało, wiązali z roponośną okolicą, z ziemią objętą w posiadanie aktem kupna, zasiedlaną i użytkowaną. W takim sensie dzieje tego miejsca są częścią dość idealistycznej polskiej historii Kresów: przestrzeni kreowania kultury materialnej i duchowej na rozległych obszarach wschodniego pogranicza ${ }^{23}$. Wytężona praca, dziedzictwo, a wreszcie następstwo pokoleń - tymi pojęciami operował Vincenz, kiedy w Lozannie u schyłku życia wspominał ojca, wyraźnie abstrahując od wielu złych doświadczeń na polu kapitalizmu, jakie stały się już jego własnym udziałem po zakończeniu pierwszej wojny światowej. W ujęciu literackim, a tak można traktować zaledwie

22 W liście do Stempowskiego z 12 lutego 1943 roku Lena Vincenz, pierwsza żona autora Potoniny, wskazywała na powinowactwo eseju Stanisława Vincenza Krajobraz jako tto dziejów z Ziemia berneńską (J.A. Choroszy, Lena. Szkice do portretu [w:] Zatrudnienie: literat. Materiaty, studia i szkice o Stanistawie Vincenzie, red. J.A. Choroszy, Wrocław 2015, s. 470). Zob. A.S. Kowalczyk, „Stepowa Hellada”. Ukraina w eseistyce i epistolografii Jerzego Stempowskiego [w:] Pogranicze kultur, red. C. Kłak, Rzeszów 1997.

${ }_{23}$ Zob. N. Tarkowska, Lecznica narodu. Kulturotwórcza rola Zaktadu Przyrodoleczniczego doktora Apolinarego Tarnawskiego w Kosowie na Pokuciu (1893-1939), Kraków 2016; K. Barański, Przeminęli zagończycy, chliborobi, chasydzi... Rzecz o ziemi stanistawowsko-kotomyjsko-stryjskiej, Londyn 1988. 
naszkicowany rozdział Stoboda wśród lasów w Barwinkowym wianku, przemilczenie obejmuje także kwestię przemysłowej, a nawet rabunkowej eksploatacji lasów i dewastacji krajobrazu naturalnego, co było niezbędnym kosztem wydobycia ropy z kilkuset szybów przy użyciu maszyn parowych. W Słobodzie dokonało się to samo, o czym pisał w Zwadzie. Powstrzymując się od zobiektywizowanej oceny dziejów nafciarskiej osady, pamiętał pisarz o usprawiedliwieniu kopalni - najpierw sięgnął do koncepcji krajobrazu jako wypadkowej „pisma światowego” i przetwórczości ludzkiej, a później odwołał się do pojęcia wspólnoty. W pierwszej argumentacji, mitycznej, sama przyroda zasygnalizowała obecność złóż ropy, co człowiek dawno spostrzegł i utrwalił w miejscowej toponimii, a z tego może wynikać, że przemysłowa eksploatacja „krwi ziemi” nie była gwałtem zadanym naturze. Drugie uzasadnienie wypowiada żydowski starzec Bercio, który jest przekonany, że „Świat jest żywy, w świecie się trzyma wszystko jedno drugiego. I ziemia też jest żywa" ${ }^{24}$. W takim rozumowaniu ziemia nie tylko chce się dzielić z człowiekiem odwiecznymi zasobami, ale i dąży do poprawienia kondycji moralnej ludzi, czemu służy ich wspólna praca: „Zamiast głowy rozbijać sobie, zamiast brzuchy rozcinać - tfu! to trzeba kopać ziemię, rozbijać skały, wiercić, tyżkować, pompować. (...) Brać tę krew ziemną na pożytek, dla uczciwego interesu"25. Naiwność Bercia została, co prawda, skontrowana przez narratora autorskiego, lecz w przekonaniach starca odbija się jak w lustrze idea Vincenza: „Bercio nie zauważył, albo nie chciał wiedzieć w ogóle, że nafta dzieli ludzi. A nawet, jak się powiada, psuje charaktery. - A to pewne, że potok ze stoku Jędrnego szeptem wezwał ludzi do jednoczenia się, a kopalnia nazwana Słoboda Rungurska po raz pierwszy wezwała ludzi pokrewnych sobie"26. Ludzkie pokrewieństwo, jak wynika z zestawienia nazwisk, stanów, statusu materialnego i narodowości nafciarzy, opiera się na stosunku do pracy i na męstwie (dzielności) w pokonywaniu przeszkód, polega głównie na zaletach charakteru, sile woli i odwadze (pionierzy naftowi są ,zastępami do walki” pod wodzą Stanisława Szczepanowskiego). Celem jednoczenia jest przede wszystkim budowa potęgi gospodarczej Galicji, a więc pożytek rozległej wspólnoty regionalnej - w planie uprzemysłowienia prowincji Słoboda Rungurska (tak jak Borysław) była kluczowym ogniwem łańcucha przedsięwzięć i inicjatyw gospodarczych (na przykład stryj Stanisława Vincenza założył w Peczeniżynie rafinerię). Dla pisarza, który tłumaczył poematy Walta Whitmana, skojarzenia z mitem amerykańskim były naturalne („Dziś pomocnicy, jutro wiertacze, później może jacyś magnaci kopalniani”) i zasadne: kresowych rycerzy wymieniły zastępy pionierów naftowych - „Amerykanie słobódzcy” ${ }^{27}$.

${ }^{24}$ S. Vincenz, Stoboda wśród lasów [w:] tegoż, Na wysokiej potoninie, t. 4: Barwinkowy wianek; Epilog, Sejny 2005, s. 161.

25 Tamże, s. 161-162.

26 Tamże, s. 162.

27 Tamże. 
Po wyczerpaniu się złóż i ograniczeniu skali wydobycia ropy pozostali w Słobodzie Rungurskiej tylko ci, którzy wrośli w krajobraz i lokalną wspólnotę, zadomowili się i nie chcieli migrować. Na zboczach odrastały lasy, a osada nafciarzy zmieniła charakter (pisał o tym Jarosław Iwaszkiewicz w 1923 roku $^{28}$ ) i powoli stawała się alternatywą dla słynnych i rojnych miejscowości letniskowych nad Prutem. Ta nowa Słoboda była dla Vincenza ciągle przestrzenią wykonywania pracy (zarządzał kopalnią), lecz w coraz większym stopniu przekształcała się w strony rodzinne, w ojcowiznę, której miejscem centralnym był stary dom. Nawet po rozwodzie z Leną i wybudowaniu się w Bystrecu wracał do środowiska, z którym czuł się związany emocjonalnie i intelektualnie, zwłaszcza od kiedy była żona stworzyła pensjonat, do którego regularnie przyjeżdżali znajomi i przyjaciele. To też należy potraktować jako istotny składnik kresowych doświadczeń typowych dla Karpat Wschodnich, zapoczątkowanych jeszcze w XVIII wieku (i opisanych między innymi przez Wincentego Pola, który trafił do Burkutu ${ }^{29}$ ), a na wielką skalę podjętych w lecznicy Apolinarego Tarnawskiego w Kosowie czy w uzdrowisku Truskawiec pod Drohobyczem. Otwarty dla gości i przyjazny dom w Słobodzie był miejscem uformowania się kolejnej wspólnoty, tym razem towarzysko-intelektualnej, był też prototypem innych sadyb obejmowanych przez Vincenzów na emigracji - w Nógrádverőce, Grenoble i La Combe, na końcu w Lozannie.

Kiedy Jacek Kolbuszewski poruszał wątek fenomenu Kresów w polskiej kulturze, to wydobywał ze sfery przemilczenia wielką tradycję, lecz mierzył się też z sentymentami, stereotypami, a nawet naukową nieufnością, czy nie mitologizuje zjawiska, które nie było wcale wyjątkowe jako przejaw pograniczności. Dowodził, że kresowość była kategorią aksjologiczną - łączyła mity i fantazmaty przedmurza chrześcijaństwa, najszlachetniejszej polskości oraz heroiczności szlacheckiego życia ${ }^{30}$. Po drugiej wojnie światowej nałożyły się na to melancholijne wyobrażenia utraconego raju, wielokrotnie zmącone pamięcią o doznanych krzywdach ${ }^{31}$.

Vincenzowe pojmowanie Kresów styka się z rzeczoną aksjologią - w przywołaniu tradycji jagiellońskiej, z której czerpali piewcy potęgi i historycznej roli dawnej Rzeczypospolitej. W osobistym doświadczeniu na plan pierwszy wysuwa się jednak przekonanie, że kresowe, pograniczne osadzenie jest szczególną formą ludzkiego istnienia: otwiera na inność, skłania do dialogu, zachęca do przekraczania barier językowych i mentalnych, wtajemnicza w cudzą

28 J. Iwaszkiewicz, Ksią̇ka moich wspomnień, Warszawa 1975, s. 240-241.

29 J.A. Choroszy, Huculszczyzna Wincentego Pola [w:] Obrazy natury i kultura. Studia o Wincentym Polu, red. M. Łoboz, Wrocław 2015, s. 110-111. Szerzej o tym: J.A. Choroszy, Huculszczyzna w literaturze polskiej, dz. cyt., s. 98-99.

30 J. Kolbuszewski, Kresy jako kategoria aksjologiczna, „Przegląd Powszechny” 1987, nr 11, s. $179-194$.

31 D. Lisak-Gębala, Literackie świadectwa kresowej melancholii [w:] W kręgu melancholii, red. A. Małczyńska, B. Małczyński, Opole-Wrocław 2010. 
duchowość, wpisuje człowieka we wspólnotę równych wobec kosmosu jednostek. Ludzka różnorodność - myśl Vincenza komentuje Sergiusz Gołowin przed kamerą Waldemara Czechowskiego ${ }^{32}$ - jest jak boska tęcza skomponowana z różnych kolorów skóry, a przecież, dodajmy, skóra jest tylko zewnętrzną powłoką, pod którą kryje się osobowość uformowana przez kulturową tradycję, i to do tych pokładów złożoności odwołuje się Vincenz. Pogranicze jest wielką - w realiach lokalnych - przestrzenią spotkania, krzyżowania się traktów i szlaków, wymiany dóbr i wartości niematerialnych ${ }^{33}$. Z punktu widzenia ulokowanego nisko i skoncentrowanego na nurtach życia codziennego trudniej dostrzec to, co ujawnia się w perspektywie kosmicznej miłości przenikającej universum, że - jak w Księciu nieztomnym Pedra Calderóna de la Barca w przekładzie Juliusza Słowackiego - świat jest tylko gospodą w kosmicznej wędrówce dusz, a celem tej wędrówki jest Ideał. Cała ludzka planeta jest marginesem (kresem) w niezmierzonej sferze galaktyk, a Pokucie staje się miniaturowym modelem kosmosu - kresowość można zatem potraktować jako kategorię ontologiczną.

Obszar pogranicza, to oddalone od centrów miejsce krzyżowania się traktów i dróg, wymaga od człowieka osiadłego gotowości do pomocy, do aktów ludzkiej zacności, świadczonych bez względu na narodowość i język. W dziele literackim Vincenza znajduje się wiele epizodów ilustrujących tę dyspozycję do zachowań altruistycznych i przyjaznych. Ich sceną są właśnie gościńce, płaje i bezdroża, a także żydowskie karczmy ${ }^{34}$ i domostwa (jak sadyby w Krzyworówni czy dom Feliksa Vincenza w Słobodzie Rungurskiej) - przestrzenie oddane we władanie prymarnym ludzkim postawom motywowanym odpowiedzialnością za drugiego, choćby nawet obcego, człowieka ${ }^{35}$. Kresy jako kategoria etyczna?

\section{Bibliografia}

Barański K., Przeminęli zagończycy, chliborobi, chasydzi... Rzecz o ziemi stanistawowsko-kotomyjsko-stryjskiej, Londyn 1988.

Burda-Fischer D., Stanistawa Vincenza tematy żydowskie, Wrocław 2015.

Choroszy J.A., Huculszczyzna w literaturze polskiej, Wrocław 1991.

Choroszy J.A., Huculszczyzna Wincentego Pola [w:] Obrazy natury i kultura. Studia o Wincentym Polu, red. M. Łoboz, Wrocław 2015.

32 Śladami Vincenza, reż. W. Czechowski, TVP 2000. Gołowin - berneńczyk, pisarz, potomek rosyjskich emigrantów - znajdował się w kręgu szwajcarskich przyjaciół autora Potoniny.

33 Koncepcję Kresów jako universum kultury zarysował Stanisław Uliasz (tenże, Kresy jako przestrzeń kulturowa [w:] Kresy-pojęcie i rzeczywistość, dz. cyt., s. 136-141).

34 D. Burda-Fischer, Stanistawa Vincenza tematy żydowskie, Wrocław 2015, s. 92.

35 S. Vincenz, Dialogi z Sowietami, Kraków 1991, s. 14. 
Choroszy J.A., Lena. Szkice do portretu [w:] Zatrudnienie: literat. Materiaty, studia i szkice o Stanistawie Vincenzie, red. J.A. Choroszy, Wrocław 2015.

Czarnik M., Stanistawa Vincenza filozofia wspótistnienia w perspektywie powojennych stosunków polsko-żydowskich, „Tematy i Konteksty” 2017, nr 7.

„Dialog o losie i duszy. Stanistaw Vincenz (1888-1971)”. Katalog wystawy, oprac. J.A. Choroszy, Wrocław 2016.

Gauden G., Lwów - kres iluzji. Opowieść o pogromie listopadowym 1918, Kraków 2019.

Hadaczek B., Huculski świat Stanistawa Vincenza [w:] tegoż, Kresy w literaturze polskiej XX wieku. Szkice, Szczecin 1993.

Hertz A., Wyznania starego cztowieka, Londyn 1979.

Iwaszkiewicz J., Książa moich wspomnień, Warszawa 1975.

Kaczmarek M., Proza pamięci. Stanistawa Vincenza pamięć i narracja, Toruń 2009.

Kolbuszewski J., Kresy jako kategoria aksjologiczna, „Przegląd Powszechny” 1987, nr 11.

Kolbuszewski J., Kresy, Wrocław 1995.

Kowalczyk A.S., „Stepowa Hellada”. Ukraina w eseistyce i epistolografi Jerzego Stempowskiego [w:] Pogranicze kultur, red. C. Kłak, Rzeszów 1997.

Kresy-pojęcie i rzeczywistość, red. K. Handke, Warszawa 1997.

Lisak-Gębala D., Literackie świadectwa kresowej melancholii [w:] Wregu melancholii, red. A. Małczyńska, B. Małczyński, Opole-Wrocław 2010.

Łoziński W., Ztotnictwo lwowskie w dawnych wiekach 1384-1640. Lwów starożytny. Kartki z historii sztuki i obyczajów, cz. 1, Lwów 1889.

Ługowska J., Vincenz - mistrz stowa mówionego, Wrocław 2015.

Madyda A., Stanistawa Vincenza antropologia kultury huculskiej [w:] tegoż, Od filologii do antropologii. Szkice, Toruń 2015.

Madyda A., Vincenz czytany dzisiaj [w:] tegoż, Od filologii do antropologii. Szkice, Toruń 2015.

Miłosz C., Gorczyńska R. (E. Czarnecka), „Podróżny świata”. Rozmowy, Kraków 2002.

Nicieja S.S., Kresowa Atlantyda. Historia i mitologia miast kresowych, t. 4: Kotomyja, Żabie, Dobromil, Opole 2014.

Ołdakowska-Kuflowa M., Stanistaw Vincenz-pisarz, humanista, orędownik zblizenia narodów. Biografia, Lublin 2006.

Tarkowska N., Lecznica narodu. Kulturotwórcza rola Zaktadu Przyrodoleczniczego doktora Apolinarego Tarnawskiego w Kosowie na Pokuciu (1893-1939), Kraków 2016.

Taylor-Terlecki N., Stanistaw Vincenz i tradycja kresowa [w:] Świat Vincenza. Studia o życiu i twórczości Stanistawa Vincenza (1888-1971), red. J.A. Choroszy, J. Kolbuszewski, Wrocław 1992.

Uliasz S., Kresy jako przestrzeń kulturowa [w:] Kresy - pojęcie i rzeczywistość, red. K. Handke, Warszawa 1997. 
Uliasz S., Literatura Kresów - kresy literatury. Fenomen Kresów Wschodnich w literaturze polskiej dwudziestolecia międzywojennego, Rzeszów 1994.

Vincenz S., Dialogi lwowskie [w:] tegoż, Po stronie dialogu, t. 2, Warszawa 1983. Vincenz S., Dialogi z Sowietami, Kraków 1991.

Vincenz S., „Madonna Busowiska”. Stowo wstęne [w:] tegoż, Po stronie dialogu, t. 2, Warszawa 1983.

Vincenz S., Ofiary w Kotomyi. Wspomnienie o Żydach kotomyjskich [w:] tegoż, Z perspektywy podróży, Kraków 1979.

Vincenz S., Outopos. Zapiski z lat 1938-1944, autograf odczytał A. Vincenz, oprac. J.A. Choroszy, Wrocław 1992.

Vincenz S., Stoboda wśród lasów [w:] tegoż, Na wysokiej potoninie, t. 4: Barwinkowy wianek; Epilog, Sejny 2005.

Wielocha A., Petro Szekeryk-Donykiw. Biografia nie catkiem kompletna, „Płaj” 2007, t. 35 .

Wittlin J., Mój Lwów, Wrocław 2017. 